This is a pre-production copy. The fully copyedited version should be referenced as: Hall, S. (2014) 'The Socioeconomic Function of Evil', in Ray. L. and Kilby, J. (eds.) Sociological Review Monograph: Violence and Society: Towards a New Sociology. Chichester: Wiley, 1331

\title{
The Socioeconomic Function of Evil
}

Steve Hall

Professor of Criminology

Teesside Centre for Realist Criminology

Teesside University, UK

\begin{abstract}
This article challenges various theories of the capitalist epoch as a process of civilization to posit a new theoretical framework built around the concept of pseudo-pacification. Principal indicators of civilizing momentum, such as the decline in homicide and brutal punishment, are relocated in a perspective that juxtaposes them with the concomitant proliferation of nonviolent crimes and the types of aggressive sociosymbolic competition that energise and structure consumer culture. What seems to have occurred is not the repression or dissipation of aggressive libidinal energy but its conversion into a dynamic yet largely pacified form that performs the dual function of protecting property and expanding production and trade by intensifying and democratising sociosymbolic competition. The pseudo-pacification process does not counteract but stimulates and reproduces aggressive drives in sublimated forms to create a fragile social peace whose potential disintegrative forces are manufactured at the very core of its own socioeconomic and cultural systems.
\end{abstract}

Keywords: capitalism, history, evil, violence, pseudo-pacification, consumer culture, libidinal energy

\section{Introduction}

Statistical evidence supports the Whiggish claim that from its nascence in the Late Middle Ages in Europe the Western liberal-capitalist era has been characterised by a decline in rates of homicide and serious violence in the public sphere (Eisner, 2001). This decline seems to have occurred alongside progress in economic productivity and individual rights. However, it was also accompanied by a notable if rather undulating rise in the rate of acquisitive property crime (Sharpe, 1996), committed increasingly for the purpose of obtaining and displaying symbols of conspicuous consumption (Hallsworth, 2005; Hall et al., 2008). This suggests not a diminution but a conversion of aggressive libidinal energy into a more pacified yet more expansive form. Thus we must consider the possibility that the liberal-capitalist epoch has not been characterised by a civilizing process but a pseudo-pacification process. This process seems to have evolved to perform the complementary tasks of sublimating libidinal energy into a form that fuels aggressive competition in the sociosymbolic field, whilst simultaneously reducing the physical violence that hampers the protection and trading of property. Therefore the pseudo-pacification process supplied the liberal-capitalist project with the invaluable combination of psychosocial momentum alongside a pacified environment conducive to the project of economic expansion. In essence, the primary purpose behind reducing and sublimating physical violence was not to establish a peaceful, sociable existence for human beings but to maintain a safer environment for the intensification and democratic 
expansion of aggressive yet rule-bound sociosymbolic competition. This chapter charts the process from its beginnings in early modernity and analyses its psychosocial dynamics. At its core, the process is reliant on the stimulation and pacified acting-out of obscene drives and object-related desires, whose generative bases are in anxiety, torment and dissociation. Acting out these drives and desires once would have attracted the label 'evil'. The aim of this chapter is not to reduce explanations of diverse manifestations of human violence to the singular effect of pseudo-pacification, but to reveal this process as a pervasive and fragile cultural current in which eruptions of various forms of violence are likely to occur as long as it continues to be a mainstay of cultural and socioeconomic life.

\section{Pseudo-pacification as a historical process}

In England, the homicide rate entered a long period of decline from the late $14^{\text {th }}$ century. From the mid- $16^{\text {th }}$ century, mainland Western Europe also experienced a similar decline. Although unknown rates of violence remained hidden in the family, the workplace and other private spaces, and there were many undulations and complexities, the general long-term historical trend in the world's first market-capitalist societies seems to have been a decline in homicide and life-threatening physical violence in the public sphere (Eisner, 2001).This seems to lend empirical weight to Elias's (1994) claim that the continent underwent a 'civilizing process'. According to Elias, the process's three mainstays are the state's monopolization of physical violence, the diffusion of behavioural codes throughout the social body, and the expansion of 'figurational' social interdependencies that drew individuals together in relations of mutual benefit and respect. The vital cultural product of this triptych of civilizing forces was the inculcation and reproduction of embodied sensibilities in the majority of individuals, who, as the subjects of new processes of sociogenesis and psychogenesis, began to react with repugnance to the gruesome consequences of physical violence and cruel punishments.

However, Elias's theory glosses over important aspects of the general field of crime, harm and violence. Apart from numerous problems associated with the relationship between culture and nature, and the lack of a clear explanation of the relation between sociogenesis and psychogenesis, it understates the continuation of brutality in the punishment system and the reproduction of exploitative social relations in the economic system. Elias understood that the 'civilizing process' was not an attempt to eliminate violence from human life, but to relocate and store it 'behind the scenes' to unleash in practices of punishment (Garland, 1990) or military violence (Fletcher, 1997). However, because he overstates the functional efficacy, neutrality and legitimacy of the state he therefore understates the violent social conflict frequently precipitated by the ineffectiveness and politicisation of the control apparatus. The thesis's explanatory framework also fails to incorporate the fragile pacifying effect of the institutionalisation of social conflict, as organised labour developed practices of negotiation with capital in the industrial capitalist era from the late $19^{\text {th }}$ century (Wieviorka, 2009). This established temporary and partial solidarity amongst the working classes and pacified what had frequently been violent social conflict over inequality, oppression and various single issues such as religious rights and food prices. Elias's rather simplified tripartite structure of civilizing forces also fails to incorporate the developing bureaucratic organisation of welfare and education systems (Mucchielli, 2010), and his rather transcendent conceptualisation of 'social' interdependencies ignores the incorporation of subjects and their fears, passions and associations into productive work; direct participation in stable forms of organised labour itself, not just the social figurations it underpins, has a vital civilizing effect 
based on the daily affirmation of the knowledge that the individual cannot survive alone (Dejours, 2003).

Constant eruptions of state violence, organised criminal violence, political violence and privatised violence in the domestic sphere and the workplace throughout the liberal-capitalist epoch, and the recent riots and the rise of violent crime in the West since the $1980 \mathrm{~s}$, all suggest that the so-called civilizing process is in its form and function actually a rather fragile and unstable pacification process, whose tripartite structure is unable to reproduce itself in a coherent and stable form, and whose ability to inculcate durable civilized emotions in subjects must be questioned. This inherent instability suggests that the process is ultimately dependent on the maintenance of a stable and supportive politico-economic environment and the constant gratification of social ambitions and private fantasy-desires inculcated in subjects by mass-mediated consumer culture (Hall et al., 2008). The tendency for individual and group violence incessantly to burst through the restraints supposedly provided by Elias's cultivated sensibilities suggests that violence was not simply concealed and 'stored up' behind physical and metaphorical walls, but that it was also 'stored up' behind the sensibilities and cultural codes that restrained its physical form and converted it to an aggressive yet pacified sociosymbolic form that displayed a tendency to revert to physicality in specific circumstances.

However, Wieviorka (2009) warns us that we cannot understand violent subjectivities as a singular undifferentiated category produced by a process of social evolution. He provides us with a typology: hypersubjectivity, the product of an overload or a plethora of meanings; desubjectivated non-subjectivity capable of surrender to the banality of evil; socially liberated antisubjectivity orientated to cruelty, sadism and violence as an end in itself; and subjectivity aimed at conserving its being or its foundation. He also reminds us that these subjectivities are the products of heterogeneous circumstances and experiences at the micro-level. However, we do not have to disagree with this pluralistic analysis and descend to crude forms of reductionism and essentialism to acknowledge the copious evidence of both long-term and short-term spatial and historical patterns of serious violence, ranging from homicide and serial killing to riots, which are quite easy to identify (Dorling, 2004; Wilson, 2007; Parker, 2008). The long-term decline in the homicide rate in Europe over the course of modernity holds true (Eisner, 2001), and a number of decades characterised by disruptive socioeconomic change - for instance neoliberal Britain and the USA in the 1980s - have suffered from abrupt rises in rates of most forms of crime and public violence (Reiner, 2007; Hall and McLean, 2009; Marktanner and Noiset, 2013). In other words, we can identify longterm periods, short-term periods and specific social spaces in which there is some degree of synchronisation in both the generative constitution and acting out of Wieviorka's differentiated categories of violent subjectivity. The following argument will show how tendencies towards these various forms of subjectivity and modes of acting them out are rooted in a long-term process of cultural change that cannot be described as a 'civilizing process', and why these differentiated forms are interrelated variants with a common root in generative conditions associated with an underlying historical process.

Mucchielli (2010) reminds us that Elias's thesis also ignores the destructive effects of sociospatial segregation and consumer culture's anti-social psychological stimulations and distractions. The ubiquity and durability of these socially disintegrative conditions and tendencies suggest that they are not simply the products of latent regressive forces released from some unknown source by temporal lapses in the maintenance of Elias's triangular framework. Mucchielli argues that the social effects of disintegrative forces - poverty, 
segregation, lack of opportunity - produce corresponding psychological effects: stress, depression, frustration, resentment, anger and so on. However, as prescient as it is, this analysis offers no answer to the question of why psychological life in these adverse conditions manifests itself in bouts of competitive consumption and violence rather than articulate political protest or rebellion. Why resort to acting out the ideologically disavowed 'dark heart' of the system - violence, looting, exploitation, infantile hedonism - rather than seeking solidarity and articulate politics in the face of adversity? Throughout the industrial era of institutionalised conflict the European working class consistently demonstrated the drive to seek and occasionally find solidarity and unifying politics in three primary forms communism, socialism and reformist social democracy - despite these conditions (Winlow and Hall, 2013).

We can agree with Mucchielli's critique of Elias's thesis and his useful additions to the explanatory framework, and with Wieviorka's (2009) appeal to abandon Elias's evolutionary approach because it simply cannot explain the conflict, heterogeneous forms of violence and violent subjectivity we have witnessed throughout the $20^{\text {th }}$ century. However, both Mucchielli and Wieviorka have trouble explaining why the post-war social democratic system of institutionalised and politicised conflict fell apart so easily in the 1980s (see Dean, 2009) to be displaced by sporadic eruptions of violent pre-political crime and rioting (Bauman, 2012; Stiegler, 2013; Treadwell, et al 2013). Although we must acknowledge and attempt to incorporate Wieviorka's formal plurality, the existence of identifiable patterns of violence suggests that our understanding is best advanced by continuing to conceptualise the types we are seeing in Europe today as the products of some sort of underlying process.

Before we investigate this process we must begin with a de-romanticising correction. The popular revisionist notion of ethnic groups peacefully accommodating each other in the intervallic Dark Age between the fall of the Roman Empire and the Late Middle Ages has been challenged by Ward-Perkins's (2005) revealing study. The decline of material production, culture and ethnic relations to prehistoric levels - the latter resulting in the death of huge proportions of European populations by blows to the head and vital organs - suggests that this period was every bit as violent as traditional historians once thought it was (see Žižek, 2010). It looks like the 'grand narrative' that from the Late Middle Ages Europe experienced as broad shift away from a notably violent period in its history - characterised by the acquisition and defence of land, treasure and bodily honour - towards the less violent acquisition of more diverse sociosymbolic resources has some purchase on reality (Hall, 2012a). The signs also point to the probability that although regions in Southern Europe began to develop market economies earlier, this mutative process first took hold more firmly in England on the back of unique legal and sociocultural changes (see Macfarlane, 1978), which we will now investigate in further detail.

After the Norman invasion disrupted the island's socio-political fabric, violent gangs took advantage of the Norman warlords' lax administration (Hibbert, 2003). By the Late Middle Ages, violence structured and reproduced a rigid class-based social order whose weak legitimacy and institutional framework were shored up by internal aggression (Maddern, 1992). In such a hostile and lawless environment the population felt safer entrenched in defensive familial and communal units. However, this lax administration also created a broader deregulated space in which wealthier peasants and merchants could accelerate the commercial development of land and urban markets. These newcomers into the economic fold realised that both authorised structural violence and unauthorised criminal violence were hampering the growth of markets (Hall, 2012a). This proto-bourgeoisie, initially attempting 
to ascend the social order by convincing monarchs that they could increase the wealth of the nation, sought a middle-way. It quickly became apparent that if property is to be safely and efficiently traded it must be protected by the rule of law, and yet, paradoxically, the expansion of this trade can be accelerated in unregulated spaces beneath the law, wealth creation can be more efficiently developed in a 'third space' created by the tension between order and disorder. Hence, in order to create this third space, the new and ambitious social group sought pacified variants of order and disorder to operate in a more stable form of dynamic tension. To protect property and allow trade the embryonic market-capitalist system required the rule of law to evacuate previously normalised physical violence from nascent commercial nodes and arteries (market towns, roads etc.). Simultaneously, the law had to sever its relation to existing customs of fair trading, yet deter violent retribution when moral judgements were cast onto the more dubious emerging practices - especially when they went awry - such as usury, cheating on weights and measures, bad debts or undercutting prices (ibid.). Physical violence was to be displaced by pacified yet aggressive, competitive and exploitative practices, which were destructive to existing customs but which could be freely encouraged and acted out as they were protected by law. The overall shift was dependent on the dual pacification of the forces of social order and disorder.

Firstly, a concerted attempt was made to gradually and partially pacify violent modes of maintaining social order. In the twelfth to thirteenth centuries, under the misgovernment of Henry III, order could not be imposed as violent gangs monopolised trading nodes and arteries, including valuable ports and market towns, and controlled the trade in precious metals (Hibbert, 2003). The ruling aristocracy's violent control methods often proved ineffective, escalating conflict as they faced these heavily-armed gangs. This palpable failure reduced public confidence in the ability of government to deal with privatised violence and protect property. Edward I, crowned in 1274, reorganised the militias and the whole criminal justice system in ways that involved the delegation of everyday citizens as agents in practices of crime control. This democratisation of control set in motion the gradual diminution of violence, to be displaced by diffused surveillance and 'social pressure' as the primary social structuring and regulatory force. This allowed more effective control of violent gangs, which created a space of reduced physical violence in which the early bourgeoisie could increase trade and the commercialisation of land in relative safety. In this environment the richer and more enterprising peasants and merchants could become more confident and active as they built the nascent market economy.

Secondly, the violent forces of social disorder were not only more efficiently repressed but significantly reconstructed. The presence of physically violent gangs, whose practices maintained brutal forms of order only at the nodal micro-level, limited market-driven economic growth at the broader level. Methods were sought to simultaneously stimulate individualised desire for new commodities yet increase pacification in civil society. The introduction of the laws of primogeniture and entail throughout the social structure in England - which were applied solely to the ruling class across the rest of Europe - from the $12^{\text {th }}$ century made families less secure places for children. This was the first step in the gradual dissolution of the family, community and land as the principal sites of honour, protection, identification and solidarity (Macfarlane, 1978), creating sibling rivalry on a new enhanced scale and extending it from the internal affective-relational dimension to the external economic dimension. This major cultural shift also significantly increased siblings' mistrust and potential hatred of parents, who from that point onwards had total arbitrary rights to property and its distribution amongst family members. The legally-driven splitting of the family, and with it the geographically-bound ethnic community, corresponds with the 
splitting of the individual ego and the redirection of its identification processes, from the family and community outward to the world of the commercial market in which offspring were forced to engage in pacified economic competition against each other as their traditional mode of security and status was disrupted. The psychosocial process was analogous to biological cell-splitting and growth, creating a sort of socioeconomic tumour as anxious subjects were cast out into competitive markets to seek wealth and establish their own domains. The overall process weakened the family as the legitimate unit of 'righteous violence' (Hall, 2012a). It risked the continued formation of violent gangs as substitute families, but as the complementary pacification and individualisation processes were gradually normalised this risk was significantly reduced.

This new insecure and competitive subjectivity become functional to the developing market economy, advantaging those who more fully embodied and practiced it; it was unprotected, vulnerable, anxious, ambitious and resentful of community and its multiple obligations. The process resembles Deleuze and Guattari's (1984) de-territorialisation, but it was more dialectical in the sense that the desire to de-territorialise and re-territorialise in a constant, circular dynamic process of expansion and proliferation was, after the initial disintegrative legal force had been applied, internally driven and reproduced rather than imposed exclusively by some extraneous political force. The process intensified, systematised and harnessed to the developing market economy the relational-subjective contradictions and hostile relations that Jameson (2010) points out as the norm in family units in the ancient world, the origin of the social dialectic. In this more recent period, however, the subject was forced to seek new security, status and identity not in the ancient cycle of Odyssey and Anabasis - the outward journey to adventure and the difficult return home to receive accolades (see Badiou, 2007) - but in the rapidly developing commercial economy, with its proliferation of symbolic objects. Many parents attempted to compensate for their legallygrounded role in this process and recover affection by doing everything they could to equip children to compete effectively in an increasingly pacified, rule-bound mode, the new measure of 'successful parenting' which persists today.

Between the Norman invasion and the Industrial Revolution, England ceased to be a standard European peasant society; it became highly individualised, competitive and oriented to small business (Bloch, 1967; Macfarlane, 1978). The individualisation process spawned a huge literature concerned with the expression of private dreams, ideals and life-projects (Thomas, 2009; Eagleton, 2009). The private pursuit of jouissance and the non-violent competition to monopolise trade displaced the traditional culturo-economic mode that had been maintained and reproduced by violence, redirecting libidinal energy to the pursuit of money and commercially distributed symbols of social distinction. The mode of acquiring material wealth and social status gradually shifted from 'somewhere', the violent defence of bodily honour and the monopolisation of trade, precious metals and land, to 'everywhere and nowhere', the pacified acquisition of the abstract values of money and social symbolism (Hall, 2012a).

Individualist culture, beginning in England and gathering tributaries from elsewhere in Europe, spread across the developing capitalist world (Dumont, 1986). The vital psychosocial element was rooted in the Lacanian principle that absence creates desire; the loss of protective, reproductive community with its durable identity became the great objet petit $a$, the unnameable lost object (see Lacan, 2007; Žižek, 2006). The replacement - the competitive individual seeking personal wealth and security in the market - became the master signifier of the new fundamental fantasy, the dream in which amorphous libidinal 
energy assumes its initial imaginary and symbolic shape to forge the individual's basic identity. In both the fundamental fantasy and the economic practice of the competitive, acquisitive entrepreneur, successful performance in the market became the principal form of combined cultural and symbolic capital, and thus, in the absence of traditional brethren, the source of ego-ideal figures in the shape of the new masters of sublimated aggressive competition (Winlow and Hall, 2009). England, the first fully industrialised imperial capitalist nation, invented a disproportionate number of the world's sports and games (see Holt, 1990) in order to encourage subjectivity - particularly male subjectivity in the shape of the 'muscular Christian' (see Whitehead, 2002) - to forge itself in an environment of rulebound aggression.

It's important to note that both poles of the human emotional spectrum were truncated for the purpose of domestication and socioeconomic utilisation. Violence was repressed and sublimated along with the impulse to concrete altruism. As the market-capitalist project developed and expanded its territorial scope from the $15^{\text {th }}$ century, the eternally difficult ethico-social task of diffusing the ideals and protocols of the community outwards to the general society and economy was abandoned (Eagleton, 2009), and laws regulating usury, wages and prices were relaxed. In many respects the opposite process prevailed as competitive market practices were introduced into communities and all social institutions; in the current neoliberal era we witness an attempt to totalise this process and bring economic history to a close. Concrete altruism was transposed into the diluted form of post hoc sentimentalism and benevolentism, which constituted Pocock's (1989) 'commercial humanism'. In a remarkable process of defeat and subjugation, capitalism confronted, sublimated, incorporated and put to work in a relation of dynamic tension its two main psychosocial threats, violence and altruism; it cannot reproduce itself in an environment dominated by either. Our culture exists in a fragile pseudo-pacified third space compressed and propelled beyond these two potent but repressed social forces and their volatile sublimatory relation; forward momentum is generated by the constant movement beyond the violence and altruism that always seek to return to their traditional places.

The process that activated and controlled the stimulation and pacification of aggressive libidinal energy in England, and, later, Europe and North America, was quite unique. Many societies disarmed and pacified their populations - indeed some might have been more civilized in the true sense of the word - but none developed with so much success the specific amalgam of pacification and sublimation required to establish la doceur du commerce (see Hirschman, 1977) and simultaneously stimulate the libidinal energy that feeds the consumerdriven market economy. The old rigid class relation had to be made more permeable and meritocratic - but only under the strict criterion of market performance - to boost individual ambition, energise markets and quell dissent and social conflict to a manageable level. The accepted route for educated and enterprising members of the lower classes was upwards through the loose and permeable class structure, which constantly releases the political pressure that can build up from below.

\section{The role of consumer culture in the pseudo-pacification process}

Social science still tends to underestimate the importance of consumer culture, as both a primary driver in early capitalist history and the dominant cultural form in the neoliberal era (Campbell, 1987; Smart, 2010). It developed as a potent dynamic force and pre-existed full industrialisation. In $14^{\text {th }}$ century Europe, when the population reduction caused by the Plague made the expansion of production and trade vital, consumer culture was propagated first 
amongst the courtly and gentrified classes as a means of increasing demand. The ascent of these groups was the first step in the gradual shift to a more permeable social structure which eased social climbing by economic means. Consumer symbolism was certainly regarded as a serious social issue; in England, as the aristocracy were troubled by the rapidity of social change, Edward III enacted secular 'sumptuary laws' to prevent the potential reversal of the sociosymbolic violence that has always played an important part in the reproduction of elite rule (Sassatelli, 2008).

The explosion of consumer culture rapidly expanded demand for luxury goods industries across Europe. By the $15^{\text {th }}$ century, entrepreneurial peasants became wealthier as navigation and superior ships opened up new sea lanes and markets began to expand. Defying the sumptuary laws and often marrying into the aristocracy to enable their social ascent, the new gentrified class started dressing in ways that imitated or in some cases outshone an aristocracy that could already sense its own decline. As consumer culture permeated social life it provided actors with a crucial sociosymbolic infrastructure whose almost unlimited ability to change its cultural codes at an increasing velocity over time (see Appadurai, 1996) combined rule-bound pacification with ruthless forms of individualised socioeconomic struggle. The heightened anxiety in England caused by familial and communal disruption drove enterprising individuals to compete harder than their European counterparts.

This dynamic movement seemed irrepressible; as the early capitalists moved into urban centres to expand trading activities and develop 'sumptuary' tastes, many began to by-pass legal restrictions on trade. They developed informal markets outside towns to avoid rents, tolls and taxes, and struck up relations with illegal traders to secure cheaper commodities and undercut prices. As many criminologists suggest, throughout this long period the distinction Max Weber (2002) made between good and bad business practice was in reality far more blurred (Hobbs, 1989). Protestant asceticism was a latecomer to a socioeconomic process already well established, acting largely as a restraint rather than a driver. Protestantism's public distaste for excess masked the underlying and very active drives for luxury and decadence, which were acted out in private aristophiliac games (Hall et al., 2008). The often rather amusing hypocrisy that resulted from this tension between private desires and public correctness was the focus of some of the best bourgeois literature (Moretti, 2013). Neither can the Weberian view of capitalism as 'ethically-driven' account for Protestant asceticism as the 'vanishing mediator' in the capitalist project (Jameson, 2010). This, and the standard Marxist notion that it is simply 'the system' and its drive for profits that damages our lives, have both obstructed intellectual enquiry into the ways in which individuals ritually by-pass ethical injunctions to perform yet simultaneously disavow their vital roles in the system's reproduction (Hall, 2012a).

As the capitalist project developed, the pseudo-pacification process became more successful in its primary task of evacuating ethical and communal values from their position as core drivers and relocating them to a new position in the socioeconomic system to meld with norms and laws and function as a strategic device to guide both action and restraint (Hall et al., 2008; Moxon, 2011). Concerned members of the bourgeoisie developed a rather schizoid and fearful attitude to the socioeconomic change they were actively promoting and, indeed, often regarded as historically inevitable. Henry Fielding, for instance, condemned moral decline and the drive for 'luxury amongst the vulgar' as he also paradoxically recognised competitive individualism and the controlled seeking of status symbols as essential for economic development (Hall, 2012a). 
As the middle classes became wealthier they also became victims of a new form of 'objectless anxiety' (Hall, 2012a; 2012b) as the socioeconomic system they promoted hollowed out social life and introduced novel, subtle and clandestine forms of 'little evils' as myriad drive-fuelled unethical practices in everyday life (Badiou, 2002). However, this anxiety - objectless because its foundation in social dissolution and the ethical and political problems it caused were ideologically disavowed and banished from everyday discourse was also the system's primary energy source. As we have seen, anxiety creates desire (Lacan, 2007; see also Roudinesco, 2014), but this amorphous, multi-purpose objectless anxiety was reproduced by the constant denial of its own objective causal condition - hollowed-out ethical and social life and the unstable economy - to become the primary stimulant in capitalism's productive and consumerised cultural life. It was highly effective because it could both create and utilise human drives to produce a new range of objective desires that constantly promise and fail to compensate for the constitutive lack that lies at the heart of subjectivity. The diversity of objective desires was limited only to the number of symbolically-laden commodities the production system could produce and circulate in markets. If we emphasise the distinction between drive and desire, here we can see clearly that the foundations of Wieviorka's (2009) typology - the loss of meaning (as fragile solidarity is constantly dissolved), the liberation of substitute meanings (as drive-fuelled desires are stimulated), and the overload of substitute meanings (as drives are repressed and sublimated to proliferate desires) - are interconnected dynamic aspects of the pseudopacification process.

As industrialisation brought affordable luxuries to the majority, the developing consumercapitalist system continued to expand the compensatory comforts in the system of signobjects that mass-mediated consumer culture now presents as a surrogate social world (Hall et al., 2008). The individual is beckoned towards painful, socially destructive and unachievable jouissance, but also restricted to a domesticated mode of acting out ambition and frustration (see Stiegler, 2009) as it declares a victory each time a fragile, temporary position of sociosymbolic distinction is achieved by pacified means (Hall et al., ibid.). In Lacanian terms, the consumer-capitalist system retained its proximity to the obscene Real, stimulating envy and anxiety (Žižek, 2010) and reworking in a pseudo-pacified form the barbaric, wasteful and violently competitive drives for the pecuniary reward, status and honour that were political currency in the Dark Ages (Veblen, 1994). The obscene drives located in the Lacanian Real were not transcended but stimulated and subsequently sublimated in a complex culturo-legal system to be rule-bound and harnessed to the economy. In the neoliberal era we are experiencing the restoration and global diffusion of this process in a borderless, minimally-regulated and technologically-enhanced form.

\section{The pseudo-pacification process falters and recovers}

The libidinal energy generated by the unstable pseudo-pacification process is highly criminogenic, the principal force behind the expansion of property crime over the course of capitalist history. The criminogenic effect is restrained at its boundary by an expansive and intrusive public/private control system. We have little choice but to make a concession to the Right and admit that the 'crime drop' the West experienced in the 1990s after the 'crime explosion' in the 1980s is largely the product of advances in the control system - smart policing, expansive social programmes, increased surveillance, mass imprisonment, DNA testing, environmental securitisation and so on operating in a context shored up by huge welfare budgets. This explanation must be combined with additional criminological factors, which include the continuation of a large realm of unrecorded 'crimes of the powerful' and 
the mutation of crime into new and only partially recorded forms such as cyber-crime, the reduction in the number of young adults in the population and the appearance of a remarkable lethargy amongst many young people (Hall, 2012a). Reflecting on his experience of teaching young people in Britain's Further Education system, Fisher (2009: 23) notes their tendency to fall into 'depressive hedonia', the 'soft narcosis, the comfort food oblivion of Playstation, allnight TV and marijuana'. We now see culture and economy working in harmony in a postpolitical world to constitute and reproduce the perfectly anxious yet docile consumer (Winlow and Hall, 2013).

None of these factors signifies an improvement in social relations or a reduction in the subjective motivation to crime and the competitive individualism that pervades Western societies. Rather, the crime-drop signifies a retreat into subjectivity (Winlow and Hall, ibid.) and the successful adaptation of the pseudo-pacification process as it adjusts its mode of operation to new circumstances laid down by neoliberalism's global economy. The dual system of pacification and control has been advanced as the techniques of stimulation were intensified to release more energy into a culturally-driven economy that offers significantly expanded opportunities for the gratification of jouissance via the acquisition of important symbolic objects and forms of entertainment in its advanced digital media systems. After a brief period of instability in the 1980s and 1990s as the neoliberal political and business elite decided to combat economic stagnation by performing the dangerous operation of downscaling social democracy's old economic regulatory system at the same time as increasing consumer pressure on the individual, the pseudo-pacification process fought back to return to operational duties in its most advanced form. Put simply, the key to the reduction in crime and violence was the expansion and improved efficiency of both 'soft' and 'hard' dimensions of the control system at the same time as the significant expansion of opportunities for even the poorer service workers and welfare recipients to act out nonviolently the drives that were stimulated further by a culture dominated by competitive individualism and consumer hedonism.

\section{The psychosocial basis of evil}

A crucial factor currently hampering social science's investigation into today's harmful forms of crime and violence is that the main philosophical schools from which it draws offer no conception of evil as drive. Only the temporary departure from prevailing ethical standards, the lust for domination amongst powerful elites, or the social reaction to 'otherness' receive critical attention. To speak of evil is condemned as pathologisation, a vestige of obsolete theological paradigms (Wieviorka, 2012). However, Jameson (2010) and Todorov and Brown (2010) argue that the good/evil duality is universal in human ethical discourse, and remind us that it's not really 'evil' as a concept that the liberal establishment worry about but the social structuring of the idea as it used to construct a pathologised 'other' on the social margins. Social science textbooks often begin with grim warnings that pathologisation was behind the evil regimes of the past - most importantly Nazism. Evil has been excised from the discourse because of the fear that it could be used to legitimise the politics of violent social reaction, which we all hope we can one day consign to the dustbin of history. Consequently, liberal thought in general has been able to replace the idea of evil as an eternal force against which we must constantly struggle with a highly diluted, temporal and individualised substitute; individuals simply 'err' as they fail to live up to cultural standards, often through no fault of their own. Thus liberalism acts as an avuncular patrician, like 'a headmaster signing off the 
end-of-year report' (Dews, 2008: 11) on individuals who tried but perhaps, with understanding and guidance, could do a little better.

This intellectual ban prevents us from even considering the possibility that some restrained and reworked form of 'evil' might exist at the very core of the socioeconomic system. The idea was certainly shared by some traditional Marxists and conservatives, such as Adorno and Eliot (see Shusterman, 1993), and it is regaining traction amongst their current equivalent pairings, such as Žižek and Sloterdijk (see Winlow and Hall, 2013), who agree on problems such as the evaporation of solidarity and public space in the heat generated by the individual competition for endless superficial novelties. Because it offends a central injunction, the idea proposed here - that the 'evil' of Dark Age violence was gradually sublimated, democratised and harnessed via sociosymbolic competition to drive the economy - risks outright rejection in the post-war liberal social-scientific establishment. However, in defence of the idea, it must be noted that very similar types of politico-cultural opportunism cropped up regularly in the discourses that accompanied most of the more economically successful civilizations. For instance, as the Chinese Legalists displaced Confucians they were quite open about their commitment to retain 'evil' and harness it to the expansion of empire with the aid of a bureaucratic state (Žižek, 2010). It was also common in political and economic circles across modern Europe; classical liberalism's economic first principle was simply an adoption of the Mandevillean notion of stimulating specific 'refined private vices' orientated to a more pacified and efficient form of economic growth, the principal 'public good' that the early bourgeoisie was interested in promoting. This method of invoking and employing the potent and volatile drives that Keynes (1935) called 'animal spirits' - drives that never learn from their consequential errors - is acknowledged with few misgivings in economic literature across the political spectrum from Adam Smith to the present day (see also Akerloff and Shiller, 2009).

European and American liberal-capitalist discourse has always displayed a fear of naturalism, the collapse of the autonomous individual's ability to withstand natural drives and forces (Dews, 2008). However, what this prevailing discourse neglects is that, with the constant accent on novelty, sensation and positive freedom, consumer culture systematically taps into drives to stimulate desires, which constantly propels the individual too close to the obscene Real, the psyche's natural core of conflicting and unnameable drives, the primal source of objectless anxiety (Hall et al., 2008; Hall, 2012b). Liberal-capitalist discourse facilitates the process negatively by deflecting critique away from consumer culture and its constantly expanding space for desire in the system of symbolic objects (Baudrillard, 2005), a space in which unleashed drives can spill out to be captured and transformed as yearnings for various commodities. When liberal-capitalism replaced various cultures based on collective orientation to the Good with a system of minimal rights (Badiou, 2002), drives were no longer directed by cultivated desires towards the transcendental Ideal, but unleashed to be harnessed by the economy. Any overspill acted out as violent or acquisitive crime is simply dissipated in a brief ritual of moral outrage and fielded on the boundary by bureaucratic institutions, which punish or try to reform or rehabilitate the individual rule-breaker. Thus, although liberal-capitalism has been moderately successful in its attempts to transcend the 'big evils' that can be committed in the service of the transcendental Ideal, because it refuses to engage intellectually or politically with drive, desire and consumer culture's techniques of stimulation and capture it remains trapped in the tension between the constant effervescence of atomised 'little evils' and the constant recourse to the potential 'big evil' of repressive, authoritarian governance (Hall, 2012a). 
What is the psychosocial source of what we have in times past called 'evil'? For many psychoanalysts it is associated with social interaction during early stages of the life-course:

Psychoanalysts, even from widely differing traditions, have concurred that evil is best understood as the attempt to inflict one's own experience of the evacuation of meaning on others. In his study of serial killers, for example, Christopher Bollas [1995] has suggested that such individuals seek to induce in others their own early experience of a total, traumatic breakdown of trust in the benignity of the adult world. (Dews, 2008: 133; see also Winlow, this volume)

This formulation casts doubt on Wieviorka's (2012) claim that evil tends to be invoked to restore meaning and control. In extreme cases trauma prevents initial formative experiences of meaning and control and is thus unable to be accepted, symbolised or explained by the child; meaning and control are never established in the first place. Such fundamental terror invokes recourse to drive, the impulse to act out without first delaying and considering the broader causes and potential consequences through ethical and rational-communicative filters. However, acting out the stimulated impulse to defend the self is impossible in such an imbalanced power relation. Constant exposure to traumatic abuse with no effective means of defence or escape represses and embodies the impulse to act in the neurological system as a latent but volatile force in the individual's plastic, adaptable pre-symbolic system of affects and emotions, which comes to the fore when exposed to symbolic actions that represent and thus trigger the memory of trauma (Winlow and Hall, 2009). Associated with the unleashing of the impulse is a primal embodied ethic, one of justifiable revenge sought to redress the original trauma and defend the self from a world populated by untrustworthy, violent others (Winlow, this volume).

However, if the subject's drive to act out extreme revenge risks being compromised by even the slightest inkling that the selected victim is not in reality the source of the original trauma, the subject enters another dimension beyond ethical justification. For Sullivan (1953), where the 'good me' is a product of love, warmth and nurturing and the 'bad me' is a product of anxiety, the psychopathic 'not me' - the dissociated self - is a product of its own ethically and intellectually unrestrained acting out of the initially repressed impulse to violence in the face of symbols of extreme threat, and the subsequent denial of the action and the impulse behind it in order to protect the self from both its own residual moral judgement and the further threat of social retribution. The 'not me' is born of absolute denial. Indeed, the threatening other can be constructed ideologically to induce fear for political purposes - the central thesis behind the standard 'fear of crime' discourse - but this can provide only a secondary aetiological analysis because the primary cause and the mechanism of denial are already established in the affective-emotional system of the subject, before violent actions can be justified and excused in socio-cultural systems of knowledge and communication. The denial of the violence of the self and its perceived identity-group is a product of the symbolic reproduction of the conditions in which trauma was experienced and the subject created itself in its fundamental fantasy (see Žižek, 2006) of the victim seeking revenge on the force that destroyed the original 'lost object' of love, trust and security, a force that can be represented by a broad spectrum of ideological symbols.

We cannot simply extend this explanation of the source of violence in extreme individual trauma to the study of violence in its broad and complex social context. Although there is little doubt that liberal-capitalism, like other unequal yet enduringly successful socioeconomic systems, was founded on traumatising episodes of violence in its founding 
phases and punctuated by similar episodes in periods of crisis (Lusordo, 2011), it certainly does not want public life to be overrun by hordes of psychopathic serial killers. However, what the liberal-capitalist socioeconomic project does require, as we have seen, is a hegemonic culture of measured aggression to fuel the dynamic force of social competition in the economy. As well as eager consumers, the system's logic also requires leading subjects to act as role-models and 'movers and shakers' at the cutting edge of its unforgivingly competitive economy, occasionally ruthless 'undertakers' who are willing to risk harm to others in order to 'get things done' in their functional business lives in a sublimated, rulebound mode of action that constantly pushes against ethical boundaries (see Hall, 2012a).

The question we must ask in future theory and research is whether an attenuated, modified variant of the potentially violent dissociated self has throughout the capitalist-modernist era been cultivated as a an everyday form of subjectivity that combines the ability to exist as a normal law-abiding citizen yet retain and act out ruthlessly aggressive impulses in nonviolent modes in the interconnected realms of consumerism, business and politics. As we have already seen in the legally-induced disruption of the family unit and the casting out of the individual into a competitive outland, 'breakdown of trust' was a traumatic formative event in the formation of English bourgeois culture. This is of course trauma of a far more subtle and variable type, but over the course of the capitalist project it has nonetheless been sustained and systematically applied to working individuals who, because they have rarely achieved a high degree of political solidarity, have only the flimsiest means of defence. In today's post-political climate (see Mouffe, 2000) the fundamental breakdown of trust in the benignity of the world has been diffused outwards from the micro-relations of the family to be reflected in broad social attitudes, which, over recent decades, seem to be harshening, not just towards the global business class and the bureaucratised and supine political class, but, more crucially, in the absence of political solidarity, towards fellow citizens (Winlow and Hall, 2013). As the majority lose sight of alternative visions of the future and become increasingly affected by negative feelings of cynicism and nihilism, anxiety is intensified and drives are re-activated. The atomised individual must compete in some way or face crushing failure in life, but in doing so risks a movement too close to the obscene Real, a possible descent into the natural uncontrolled drives that to liberal discourse is the one true evil that still exists in a latent form, currently restrained by relocated ethics acting as 'strategic normative practices' backed up on the boundary by a repressive external system of control.

\section{Concluding remarks}

Liberal-capitalism was an experiment with the length of the libidinal leash, to see how far it could be released and in what ways drives could be stimulated, sublimated, restrained and disciplined before they became socially toxic. The culture that accompanied this epoch cannot be seen as a 'civilizing process' or a 'disciplinary society', except insofar as it acted as a restraining mechanism on pre-existing drives that have been systematically stimulated for specific political and economic purposes. Rather, the simultaneous functional stimulation and control of libidinal drives constitutes a pseudo-pacification process. This process generates immense undialectical tension between stimulated obscene drives and a complex system of desire-formation, repression, sublimation and economic utilisation. This is not simply desire manipulated to serve control, as Marcuse (1991) suggested; desire is genuinely free to seek its objects, but the media-marketing system monopolises the communicative space in which objects are socially valued and sought. Control - unwieldy, expensive and anathema to neoliberalism's core ethos of cost-cutting and downsizing public institutions - is the reluctant 
means, not the end, in a process that serves stimulation, pacification, economic growth and profitability.

In a process that constantly and systematically stimulates a pervasive sense of loss and trauma, the meaning and control that Wieviorka (2012) claims the subject seeks to 'restore' has never been fully experienced. Social peace became dependent on the constant expansion of the arena in which the majority can compete over economic opportunities and sociosymbolic status by pseudo-pacified means. We all need to consume, but deep incorporation into consumerism's culture of jouissance distracts the mass of working-class individuals from fully committed involvement in the politics of solidarity (Winlow and Hall 2012; 2013). If 'evil' is the product of the breakdown of solidarity and trust and the subsequent activation of the malignant will in an unmediated connection to death drive, which seeks its enjoyment in the destruction of all meaning and morality and the infliction of its painful experience of this on the other, it is not difficult to understand how this force can be invoked and repressed in an attenuated form that is quite easily sublimated by the indiscriminately competitive sociosymbolic world of consumer culture and harnessed to capitalist production. However, first it must be stimulated as drive, and this is the danger. People are not immutably 'evil', but our culture rests on a bedrock of over-stimulated drives that can cut through systems of ethico-rational mediation and external control to fuel antisocial and violent actions when the promise of an endless supply of opportunities for economic prosperity and sociosymbolic ascendance is threatened.

\section{References}

Akerloff, G. and Shiller, R., (2009), Animal Spirits: How Human Psychology Drives the Economy, and Why It Matters for Global Capitalism, Princeton: Princeton University Press.

Appadurai, A., (1996), Modernity at Large: Cultural Dimensions of Globalization, Minneapolis: University of Minnesota Press.

Badiou, A., (2002), Ethics: An Essay on the Understanding of Evil, London: Verso.

Badious, A., (2007), The Century, Cambridge: Polity.

Baudrillard, J., ([1968]2005), The System of Objects, London: Verso.

Bauman, Z., (2012), 'Fuels, Sparks and Fires: On Taking to the Streets', Thesis Eleven, 109: 11-6.

Bloch, M., (1967), Land and Work in Mediaeval Europe, London: Routledge and Kegan Paul.

Bollas, C., (1995), Cracking Up, London: Routledge.

Campbell, C., (1987), The Romantic Ethic and the Spirit of Modern Consumerism, Oxford: Blackwell. 
Dean, J., (2009), Democracy and Other Neoliberal Fantasies: Communicative Capitalism and Left Politics, Durham, NC: Duke University Press.

Dejours, C., (2003), L'Evaluation du travail à l'épreuve du reel, Paris: INRA Editions.

Deleuze, G. and Guattari, F., (1984), Anti-Oedipus: Capitalism and Schizophrenia, London: Athlone.

Dews, P., (2008), The Idea of Evil, Oxford: Blackwell.

Dorling, D., (2004), 'Prime Suspect: Homicide in Britain', in P. Hillyard, C. Pantazis, S. Tombs, \& D. Gordon (eds.), Beyond Criminology: Taking Harm Seriously, London: Pluto.

Dumont, L., (1986), Essays on Individualism: Modern Ideology in Anthropological Perspective, Chicago: University of Chicago Press.

Eagleton, T., (2009), Trouble with Strangers: A Study of Ethics, Chichester: WileyBlackwell.

Eisner, M., (2001), 'Modernization, Self-control and Lethal Violence: The Long-term Dynamics of European Homicide Rates in Theoretical Perspective', British Journal of Criminology, 41: 618-38.

Elias, N., (1994), The Civilizing Process, Oxford: Blackwell.

Fletcher, J., (1997), Violence and Civilization, Cambridge: Polity.

Fisher, M., (2009), Capitalist Realism: Is There No Alternative?, Alresford: Zero Books.

Garland, D., (1990), Punishment and Modern Society, Oxford: Clarendon.

Hall, S., Winlow, S. and Ancrum, C., (2008), Criminal Identities and Consumer Culture: Crime, Exclusion and the New Culture of Narcissism, Cullompton: Willan.

Hall, S. and McLean, C., (2009), 'A Tale of Two Capitalisms: Pleminary Spatial and Historical Comparisons of Homicide Rates in Western Europe and the USA', Theoretical Criminology, 13(3): 313-39.

Hall, S., (2012a), Theorizing Crime and Deviance: A New Perspective, London: Sage

Hall, S., (2012b), 'The Solicitation of the Trap: On transcendence and transcendental materialism in advanced consumer-capitalism', Human Studies: Special Issue on Transcendence and Transgression, 35(3): 365-381.

Hall, S., (2012c), 'Don't Look Up, Don't Look Down: Liberal criminology's fear of the supreme and the subterranean', Crime, Media, Culture: Special Issue: York Deviancy Conference 2011, 8(2): 197-212.

Hallsworth, S., (2005), Street Crime, Cullompton: Willan 
Hibbert, C., (2003), The Roots of Evil, Stroud: Sutton.

Hirschman, A., (1977) The Passions and the Interests, Princeton: Princeton University Press.

Hobbs, D., (1989), Doing the Business: Entrepreneurship, the Working Class, and Detectives in the East End of London, Oxford: Oxford University Press.

Holt, R., (1990) Sport and the British: A Modern History, Oxford: Clarendon Press.

Jameson, F., (2010), Valences of the Dialectic, London: Verso.

Keynes, J.M., (1935), The General Theory of Employment, Interest and Money, New York: Harcourt, Brace and Co.

Lacan, J., (2007), Ecrits, New York: Norton.

Lusordo D., (2011), Liberalism: A Counter History, London: Verso.

Macfarlane, A., (1978), The Origins of English Individualism: The Family, Property and Social Transition, Oxford: Blackwell.

Maddern, P., (1992), Violence and Social Order: East Anglia 1422-1442, Oxford: Oxford University Press.

Marcuse, H., ([1964]1991), One-Dimensional Man: Studies in Ideology of Advanced Industrial Society, $2^{\text {nd }}$ edition, London: Routledge.

Marktanner, M. and Noiset, L., (2013), 'Social versus conservative democracies and homicide rates', International Journal of Social Economics, 40(4): 292-310.

Moretti, F., (2013), The Bourgeois: Between History and Literature, London: Verso.

Mouffe, C., (2000), The Democratic Paradox, London: Verso.

Moxon, D., (2011), 'Consumer Culture and the 2011 'Riots', Sociological Research Online, 16(4): 19.

Mucchielli, L., (2010), 'Are We Living in a More Violent Society? A Socio-historical Analysis of Interpersonal Violence in France, 1970s-Present', British Journal of Criminology, 50(5): 808-29.

Parker, K.F., (2008), Unequal Crime Decline: Theorizing Race, Urban Inequality and Criminal Violence, New York: New York University Press.

Pocock, J., (1989), 'Civic Humanism and Its Role in Anglo-American Political Thought', in Pocock, J. (ed.) Politics, Language and Time: Essays on Political Thought and History, Chicago: University of Chicago Press.

Reiner, R., (2007) Law and Order: An Honest Citizen's Guide to Crime and Control, Cambridge: Polity. 
Roudinesco, É., (2014), Lacan: In Spite of Everything, London: Verso.

Sassatelli, R., (2008), Consumer Culture: History, Theory and Politics, London: Sage.

Sharpe, J., (1996), Crime in Early Modern England 1550-1750, Harlow: Longman.

Shusterman, R., (1993), 'Eliot and Adorno on the Critique of Culture', Theory, Culture and Society, 10, 25-52.

Smart, B., (2010), Consumer Society: Critical issues and Environmental Consequences, London: Sage.

Stiegler, B., (2009), Acting Out (trans. D. Barison, D. Ross and P. Crogan), Stanford: Stanford University Press.

Stiegler, B., (2013), Uncontrollable Societies of Disaffected Individuals, Cambridge: Polity.

Stein, A., (2007), Prologue to Violence: Child Abuse, Dissociation and Crime, Mahwah, NJ: The Analytic Press.

Sullivan, H.S., (1953), Conceptions of Modern Psychiatry, New York: W.W. Norton.

Thomas, K., (2009), The Ends of Life: Roads to Fulfilment in Early Modern England, Oxford: Oxford University Press.

Todorov, T. and Brown, A., (2010), The Fear of Barbarians, Cambridge: Polity.

Treadwell, J., Briggs, D., Winlow, S. and Hall, S., (2013), 'Shopocalypse Now: Consumer culture and the English riots of 2011', British Journal of Criminology, 53(1): 1-17.

Veblen, T., ([1899]1994), The Theory of the Leisure Class, London: Penguin.

Ward-Perkins, B., (2005), The Fall of Rome and the End of Civilization, Oxford: Oxford University Press.

Weber, M., (2002), The Protestant Ethic and the Spirit of Capitalism (trans. S. Kalberg), Oxford: Blackwell

Whitehead, S., (2002), Men and Masculinities: Key Themes and New Directions, Cambridge: Polity.

Wieviorka, M., (2009), Violence: A new approach, London: Sage.

Wieviorka, M., (2012), Evil, Cambridge: Polity.

Wilson, D., (2007), Serial Killers: Hunting Britons and their victims 1960-2006, Sherfieldon-Loddon: Waterside Press. 
Winlow, S. and Hall, S., (2009), 'Retaliate First: Memory Humiliation and Male Violence', Crime, Media, Culture, 5(3): 285-304.

Winlow, S. and Hall, S., (2012), 'A Predictably Obedient Riot: Postpolitics, Consumer Culture, and the English Riots of 2011', Cultural Politics, 8(3): 465-488.

Winlow, S. and Hall, S., (2013), Rethinking Social Exclusion: The End of the Social?, London: Sage.

Winlow, S., (2014), 'Trauma, guilt and shame: Some theoretical notes on violent subjectivity', this volume.

Žižek, S., (2006), How to Read Lacan, London: Granta.

Žižek, S., (2010), Living in the End Times, London: Verso. 